\title{
Hemophagocytic Lymphohistiocytosis Associated with Coinfection of Scrub Typhus and Dengue Fever in a Child: A Case Report
}

\author{
Çocuklarda Çalılık Tifüsü ve Dang Ateşi Koenfeksiyonuna Bağlı Hemofagositik \\ Lenfohistiyositoz: Bir Olgu Sunumu
}

\author{
(D) H. C. Krishna KUMAR, (1) K. Jagadish KUMAR, (1) Manjunath V. G., (D) Sangeetha BALAJI \\ JSS Academy of Higher Education and Research, JSS Medical College, Department of Pediatrics, Mysore, India
}

\section{Abstract}

Hemophagocytic lymphohistiocytosis $(\mathrm{HLH})$ is an uncommon life-threatening immune disorder that may be either primary or secondary to infection, malignancy, or rheumatological disease. In tropical countries like India, secondary HLH is more commonly seen. Both Dengue fever and scrub typhus, which result in more than half of all acute undifferentiated febrile illnesses in tropics, can occasionally result in $\mathrm{HLH}$. Early diagnosis of HLH and institution of appropriate treatment can result in a good outcome. Although coinfections are common in tropical countries, HLH due to coinfections is rare. We are reporting a child diagnosed with $\mathrm{HLH}$ associated with coinfection with scrub typhus and Dengue fever that received early supportive treatment and recovered without needing chemotherapy.

Keywords: Hemophagocytic lymphohistiocytosis, Dengue infection, scrub typhus, coinfection

Öz

Hemofagositik lenfohistiyositoz $(H L H)$, birincil olabilen veya enfeksiyon, malignite veya romatolojik hastalığa ikincil olabilen, hayatı tehdit eden ve nadir görülen bir bağışıkıı sistemi bozukluğudur. Hindistan gibi tropikal ülkelerde ikincil HLH daha yaygın olarak görülmektedir. Tropik bölgelerde tüm akut ateşli hastalıkların yarısından fazlasına neden olan Dang humması ve çalılık tifüsü bazen HLH ile sonuçlanabilir. HLH'nin erken teşhisi ve uygun tedavisi iyi bir sonuç alınmasını sağlayabilir. Tropikal ülkelerde koenfeksiyonlar yaygın olmasına rağmen, koenfeksiyonlara bağlı HLH nadirdir. Erken destek tedavisi gören ve kemoterapiye ihtiyaç duymadan iyileşen, çalılık tifüsü ve Dang humması koenfeksiyonuyla ilişkili HLH teşhisi konan bir çocuğu, bu yazıda bildiriyoruz.

Anahtar Kelimeler: Hemofagositik lenfohistiyositoz, Dang enfeksiyonu, çalılık tifüsü, koenfeksiyon

\section{Introduction}

Hemophagocytic Iymphohistiocytosis $(\mathrm{HLH})$ is a syndrome that is characterized by immune dysregulation due to inappropriate hyperinflammatory immune response ${ }^{[1]}$. It can be primary, due to a genetic defect of natural killer (NK) cells and cytotoxic T-lymphocytes, or secondary, because of strong immunological activation associated with infections or rheumatic or autoimmune disorders ${ }^{[2]}$. Secondary HLH is more common than primary $\mathrm{HLH}$, especially in tropical countries. Although viral infections are commonly implicated in $\mathrm{HLH}_{\text {, }}$ other infectious agents, such as bacteria, protozoa, and fungi, can also result in $\mathrm{HLH}^{[2]}$. Hemophagocytic lymphohistiocytosis is characterized by NK T-cell malfunction, proliferation, and activation of lymphocytes or histiocytes, with uncontrolled hemophagocytosis and cytokine overproduction ${ }^{[3]}$. In secondary $\mathrm{HLH}$, predisposing conditions lead to immune dysregulation, and in such instance, the most common infectious agent is

Cite this article as: Kumar HCM, Kumar KJ, VG M, Balaji S. Hemophagocytic Lymphohistiocytosis Associated with Coinfection of Scrub Typhus and Dengue Fever in a Child: A Case Report. Mediterr J Infect Microb Antimicrob. 2021;10:20. 
Epstein-Barr virus (EBV) ${ }^{[4]}$. In tropical countries coinfections are also quite common, and they can be complicated with $\mathrm{HLH}$, which could be fatal. Hemophagocytic lymphohistiocytosis is a potentially treatable condition, which is often missed due to the lack of suspicion. Herewith, we report a rare case of $\mathrm{HLH}$ associated with coinfection with scrub typhus and Dengue fever in a child.

\section{Case Report}

A 3-year-old female presented with a history of fever for twelve days, rashes for four days, and abdominal pain associated with vomiting for two days. There was no history of cough or bowel and bladder disturbances. On examination, The child was febrile (with a temperature of $101.2^{\circ} \mathrm{F}$ ). She had a pulse rate of 140 beats/min, respiratory rate of 58 breaths/min, blood pressure level of $92 / 50 \mathrm{mmHg}$, capillary filling time of less than three seconds, and oxygen saturation $\left(\mathrm{SpO}_{2}\right)$ level of $98 \%$ on room air. She had a flush, puffy eyelids, right axillary lymphadenopathy, pedal edema, and generalized erythematous maculopapular rashes, sparing the palms and soles. An eschar was present in the left groin measuring about $1 \mathrm{~cm} \times 0.5 \mathrm{~cm}$. Abdominal examination revealed a $4 \mathrm{~cm}$ hepatomegaly and $2 \mathrm{~cm}$ splenomegaly. Examination of other systems was unremarkable. The diagnostic and blood tests, which were conducted, are shown in Table 1.

She was diagnosed with scrub typhus/Dengue fever/Kawasaki disease on admission and started on oral doxycycline and intravenous (IV) ceftriaxone. Fresh frozen plasma was given as the coagulation profile was deranged. In view of the presence of hepatosplenomegaly, bicytopenia, raised aspartate aminotransferase, and increased prothrombin time and activated partial thromboplastin time in a patient febrile for 12 days, HLH was suspected, and inflammatory markers were sent. A diagnosis of HLH was made based on the criteria, and the patient was closely monitored. She became afebrile 24 hours after admission. Her puffiness and pedal edema subsided by the third day. The patient was discharged on the seventh day. Oral doxycycline was given for 10 days. During the follow-up after 15 days, the patient was afebrile and active. Informed consent was obtained from the parents.

\section{Discussion}

Hemophagocytic lymphohistiocytosis is an uncommon inflammatory disorder, characterized by activation of macrophages that cause the phagocytosis of blood cells in bone marrow. The diagnosis of $\mathrm{HLH}$ is based on either the presence of a molecular diagnosis alone or the presence of at least five of the following eight criteria: fever, splenomegaly, bicytopenia, hypertriglyceridemia and hypofibrinogenemia, hemophagocytosis in bone marrow/spleen/lymph nodes, low/ absent NK cell activity, hyperferritinemia, and high soluble IL-2 receptor levels ${ }^{[1]}$. Five of the aforementioned criteria were present in our patient, which is required for the diagnosis of HLH. In HLH, sIL2r and NK cell function are important objective markers of increased T-cell activity and impaired cytotoxic function, respectively ${ }^{[4]}$. Perforin and CD107a tests are superior to NK cell function testing for screening for genetic $\mathrm{HLH}^{[5]}$. However, we could not perform these investigations because of lack of facilities in our center.

Zhou et al. ${ }^{[3]}$ reported HLH as a complication of scrub typhus in six children. Jin et al. ${ }^{[6]}$ reported HLH associated with scrub typhus in 16 children. Veerakul et al. ${ }^{[7]}$ reported secondary HLH in 52 children, out of which 15 had HLH due to infections and three had HLH due to Dengue fever. A study from Puerto Rico observed 33 children with $\mathrm{HLH}$, out of which 28 had acquired $\mathrm{HLH}$ and 22 had HLH associated with Dengue fever ${ }^{[8]}$.

Coinfections are common in tropical countries and pose a challenge to the clinician. Many dual infections are reported, but reports on HLH due to coinfections are few ${ }^{[8-10]}$. Khurram et al. ${ }^{[9]}$ reported HLH due to Dengue and malaria in a 19-yearold boy. Choudhary et al. ${ }^{[10]}$ reported HLH in a 5-year-old child with hepatitis $A$ and $E$, who passed away. Ellis et al. ${ }^{[8]}$ reported HLH due to coinfections in five children where two of them had Dengue and herpes simplex virus, one had Dengue and respiratory syncytial virus and EBV, and one had EBV with coxsackievirus.

Our patient was of a low socioeconomic status from a rural background, where Dengue fever and scrub typhus are endemic. She had both scrub typhus and Dengue infection, causing acquired HLH. To the best of our knowledge, till now no cases of coinfection of scrub typhus and dengue fever in association with HLH has been reported in the literature. Our patient presented with fever that lasted for 12 days, puffy eyelids with maculopapular rash, and eschar. We diagnosed her as having scrub typhus/Dengue fever. Her Weil-Felix test was positive with high titers, and ELISA for Dengue NS-1 antigen was also positive. Weil-Felix test has a sensitivity and specificity of $15.82 \%$ and $96.6 \%$, respectively ${ }^{[11]}$. The sensitivity and specificity of NS1 ELISA were $89.9 \%$ and $100 \%$, respectively ${ }^{[12]}$.

In India, both Dengue and scrub infections are endemic with overlapping clinical features and result in more than half of all acute undifferentiated febrile illnesses ${ }^{[13]}$. Both share similar clinical presentations and pose a challenge to clinicians when differentiating between them. According to clinical score to differentiate scrub typhus and Dengue (CSSD), our patient had a CSSD that favored Dengue fever but presented with an eschar ${ }^{[13]}$. Eschar is pathognomonic of scrub typhus and can be identified in only $20-54 \%$ of patients ${ }^{[13]}$. 
Table 1. Diagnostic and blood tests

\begin{tabular}{|c|c|c|c|c|c|c|}
\hline Diagnostic and blood tests & Day 1 & Day 2 & Day 3 & Day 4 & Day 6 & Day 14 \\
\hline Hemoglobin $(n=11-14 \mathrm{~g} / \mathrm{dl})$ & 8.9 & 9.4 & 9.3 & 9.0 & 9.7 & \\
\hline Hematocrit ( $n=33-43 \%)$ & 28.1 & 28.5 & 28.5 & 26.8 & 29.3 & \\
\hline WBC $\left(n=4,000-12,000\right.$ cells $\left./ \mathrm{mm}^{3}\right)$ & 4600 & 6,020 & 5,890 & 5,490 & 5,530 & \\
\hline Neutrophils ( $\mathrm{n}=54-62 \%)$ & 24.1 & 21.9 & 17.1 & 18.6 & 27.4 & \\
\hline Lymphocytes (n=25-33\%) & 74.4 & 72.3 & 76.4 & 75.4 & 65.9 & \\
\hline Platelets $(\mathrm{n}=1.5-4$ lakh cells/mm³) & 35,000 & 48,000 & 50,000 & 116,000 & 308,000 & \\
\hline PT $(\mathrm{n}=12.2-15.5 \mathrm{sec})$ & 17.5 & & & & & \\
\hline INR $(\mathrm{n}=1.1$ or below $)$ & 1.43 & & 1.11 & & & \\
\hline aPT (n=26.5-35.5 sec) & $>3 \min$ & & 35 & & & \\
\hline $\operatorname{CRP}(\mathrm{n}=<6 \mathrm{mg} / \mathrm{dl})$ & 50.44 & & & & 2.22 & \\
\hline Bilirubin total $(\mathrm{n}=<1 \mathrm{mg} / \mathrm{dl})$ & 0.42 & & & & & \\
\hline Bilirubin direct $(\mathrm{n}=<0.2 \mathrm{mg} / \mathrm{dl})$ & 0.25 & & & & & \\
\hline $\operatorname{RBS}(\mathrm{n}=60-100 \mathrm{mg} / \mathrm{dl})$ & 85 & & & & & \\
\hline Albumin $(\mathrm{n}=3.5-5.5 \mathrm{~g} / \mathrm{dl})$ & 2.7 & & & & & \\
\hline ALT (n=5-45 IU/I) & 102 & & 101 & & & \\
\hline AST $(n=20-45 \mathrm{IU} / \mathrm{I})$ & 400 & & 198 & & & \\
\hline $\operatorname{ALP}(n=100-420 \mathrm{IU} / \mathrm{I})$ & 221 & & & & & \\
\hline Urea $(\mathrm{n}=5-25 \mathrm{mg} / \mathrm{dl})$ & 20 & & & & & \\
\hline Creatinine $(\mathrm{n}=0.12-1.00 \mathrm{mg} / \mathrm{dl})$ & 0.26 & & & & & \\
\hline Sodium ( $\mathrm{n}=135-145 \mathrm{mEq} / \mathrm{l})$ & 127 & & 133 & & & \\
\hline Potassium $(\mathrm{n}=3.5-5.5 \mathrm{mEq} / \mathrm{l})$ & 4.0 & & 4.7 & & & \\
\hline Serum LDH (n=150-450 IU/I) & 1,260 & & & & 443 & \\
\hline Triglycerides $(\mathrm{n}=<150 \mathrm{mg} / \mathrm{dl})$ & & 506 & & & & 359 \\
\hline Ferritin $(\mathrm{n}=13-150 \mathrm{ng} / \mathrm{ml})$ & & 5,534 & & & & 22.2 \\
\hline Troponin T $(\mathrm{n}=0.0127-0.0249 \mathrm{ng} / \mathrm{ml})$ & & 0.011 & & & & \\
\hline CK-MB (n=<5 ng/ml) & & 1.51 & & & & \\
\hline Weil-Felix: OXK & 1:320 positive & & & & & \\
\hline 0X-2 and $0 X-19$ & $<1: 80$ & & & & & \\
\hline Dengue (ELISA): NS1 Ag & Positive & & & & & \\
\hline $\lg \mathrm{M}$ & Negative & & & & & \\
\hline Widal test & Negative & & & & & \\
\hline Peripheral blood smear for malarial parasites & Not seen & & & & & \\
\hline Urine routine & Normal & & & & & \\
\hline 2D ECHO & Normal & & & & & \\
\hline USG abdomen & \multicolumn{6}{|c|}{ Polyserositis, cystitis, and hypoechoic nodules in spleen } \\
\hline Blood culture & No growth & & & & & \\
\hline
\end{tabular}

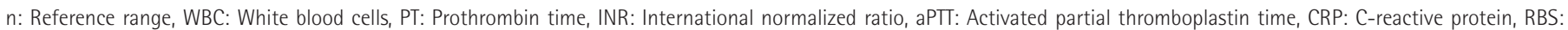

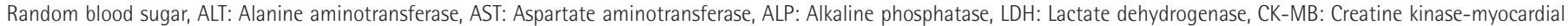
band, IgM: Immunoglobulin M, USG: Ultrasonography, ECHO: Echocardiography

Jin et al. ${ }^{[6]}$ treated HLH due to scrub typhus with antirickettsial antibiotics in 15 of 16 patients. Dexamethasone was required in only two severe cases, one of which died due to multiorgan failure. They opined that use of chemotherapy in HLH associated with scrub typhus in children may be unnecessary. A systematic review of $\mathrm{HLH}$ associated with scrub typhus revealed that treatment with a single antibiotic in 16 of 30 cases showed improvement. The additional therapies used were dexamethasone (2 of 30 patients), etoposide chemotherapy (3 of 30 patients), cyclosporine ( 1 of 30 patients), intrathecal methotrexate (1 of 30 patients), and IV immunoglobulin (7 of 30 patients) ${ }^{[14]}$. Our patient also responded to doxycycline 
after 24 hours and showed a steady progressive improvement. Therefore, bone marrow aspiration was deferred, and treatment with immunosuppressants was not initiated. In HLH associated with scrub typhus treated with antibiotics, rapid defervescence is observed. Doxycycline and minocycline possess antiinflammatory effects and modulate cytokine levels and may be responsible for the rapid defervescence ${ }^{[14]}$. When treating $\mathrm{HLH}$, glucocorticoids were included, and beyond this, there is a considerable variation in the treatment ${ }^{[4]}$. Currently, even though ruxolitinib is recommended for refractory/relapsed $\mathrm{HLH}$ as a salvage treatment regimen, Zhang et al. ${ }^{[15]}$ opined that their study supports the possibility of ruxolitinib-targeted therapy for secondary HLH in children. In a study by Locatelli et al. ${ }^{[16]}$, emapalumab (a human anti-interferon- $\gamma$ antibody) was effective in patients with primary HLH. They concluded that their study supports further investigation of emapalumab in patients with secondary HLH in whom interferon $\gamma$ has been suggested to be pathogenic.

\section{Conclusion}

In countries like India, where many infections are endemic, dual infections are quite common. Moreover, most of these infections can lead to HLH. Hence, a high index of suspicion for HLH should be present as prompt early and appropriate management can avoid unnecessary use of steroids and chemotherapeutic drugs.

\section{Ethics}

Informed Consent: Informed consent was obtained from the parents.

Peer-review: Externally peer-reviewed.

\section{Authorship Contributions}

Concept: H.C.K.K, K.J.K., S.B., Design: H.C.K.K, K.J.K., Data Collection or Processing: K.J.K., M.V.G., S.B., Analysis or Interpretation: H.C.K.K, K.J.K., Literature Search: K.J.K., M.V.G., S.B., Writing: H.C.K.K, S.B.

Conflict of Interest: No conflict of interest was declared by the authors.

Financial Disclosure: The authors declared that this study received no financial support.

\section{References}

1. Henter Jl, Horne A, Aricó M, Egeler M, Filipovich A, Imashuku S, Ladisch S, McClain K, Webb D, Winiarski J, Janka G. HLH- 2004: diagnostic and therapeutic guidelines for hemophagocytic lymphohistiocytosis. Pediatr Blood Cancer. 2007:48:124-31.
2. Janka GE. Familial and acquired hemophagocytic lymphohistiocytosis. Annu Rev Med. 2012;63:233-46.

3. Zhou YH, Xia FQ, Van Poucke S, Zheng MH. Successful treatment of scrub typhus-associated hemophagocytic lymphohistiocytosis with chloramphenicol: report of 3 pediatric cases and literature review. Medicine (Baltimore). 2016;95:e2928.

4. Hayden A, Park S, Giustini D, Lee AY, Chen LY. Hemophagocytic syndromes (HPSs) including hemophagocytic lymphohistiocytosis (HLH) in adults: A systematic scoping review. Blood Rev. 2016;30:411-20.

5. Rubin TS, Zhang K, Gifford C, Lane A, Choo S, Bleesing JJ, Marsh RA. Perforin and CD107a testing is superior to NK cell function testing for screening patients for genetic HLH. Blood. 2017;129:2993-9.

6. Jin $Y M$, Liang $D S$, Huang $A R$, Zhou AH. Clinical characteristics and effective treatments of scrub typhus-associated hemophagocytic lymphohistiocytosis in children. J Adv Res. 2018;15:111-6.

7. Veerakul G, Sanpakit K, Tanphaichitr VS, Mahasandana C, Jirarattanasopa N. Secondary hemophagocytic lymphohistiocytosis in children: an analysis of etiology and outcome. J Med Assoc Thai. 2002;85:S530-41.

8. Ellis EM, Sharp TM, Pérez-Padilla J, González L, Poole-Smith B K, Lebo E Baker C, Delorey MJ, Torres-Velasquez B, Ochoa E, Rivera-Garcia B, DíazPinto $\mathrm{H}$, Clavell L, Puig-Ramos A, Janka GE, Tomashek KM. Incidence and risk factors for developing dengue-associated hemophagocytic lymphohistiocytosis in Puerto Rico, 2008 - 2013. PLoS Negl Trop Dis. 2016;10:e0004939.

9. Khurram M, Faheem M, Umar M, Yasin A, Qayyum W, Ashraf A, Khan JZ, Yasir AH, Ansari Y, Asad M, Khan I, Abbas S, Rasheed I, Rasool N, Bushra Khar HT. Hemophagocytic lymphohistiocytosis complicating dengue and plasmodium vivax coinfection. Case Rep Med. 2015;2015:696842.

10. Choudhary SK, Agarwal A, Mandal RN, Grover R. Hemophagocytic lymphohistiocytosis associated with hepatitis a and hepatitis e coinfection. Indian J Pediatr. 2016;83:607-8.

11. Kannan K, John R, Kundu D, Dayanand D, Abhilash KPP, Mathuram AJ, Zachariah A, Sathyendra S, Hansdak SG, Abraham OC, Gunasekaran K, lyadurai $R$, Abraham AM, Prakash JAJ, Yesudhason BL, Veeraraghavan B, Kavitha ML, Jose LR, Sumana MN, Saravu K, Varghese GM. Performance of molecular and serologic tests for the diagnosis of scrub typhus. PLoS Negl Trop Dis. 2020;14:e0008747.

12. Gaikwad S, Sawant SS, Shastri JS. Comparison of nonstructural protein-1 antigen detection by rapid and enzyme-linked immunosorbent assay test and its correlation with polymerase chain reaction for early diagnosis of dengue. J Lab Physicians. 2017;9:177-81.

13. Mitra S, Gautam I, Jambugulam M, Abhilash KP, Jayaseeelan V. clinical score to differentiate scrub typhus and dengue: a tool to differentiate scrub typhus and dengue. J Glob Infect Dis. 2017;9:12-7.

14. Naoi $T$, Morita $M$, Kawakami $T$, Fujimoto $S$. Hemophagocytic lymphohistiocytosis associated with scrub typhus: systematic review and comparison between pediatric and adult cases. Trop Med Infect Dis. 2018;3:19.

15. Zhang Q, Wei A, Ma HH, Zhang L, Lian HY, Wang D, Zhao YZ, Cui L, Li WJ, Yang Y, Wang TY, Li ZG, Zhang R. A pilot study of ruxolitinib as a front-line therapy for 12 children with secondary hemophagocytic lymphohistiocytosis. Haematologica. 2020 Jul 30. Online ahead of print

16. Locatelli $F_{\text {, Jordan } M B}$, Allen $C$, Cesaro $S$, Rizzari $C$, Rao A, Degar $B$, Garrington TP, Sevilla J, Putti M-C, Fagioli $F$, Ahlmann M, Dapena Diaz J-L, Henry M, De Benedetti F, Grom A, Lapeyre G, Jacqmin P, Ballabio $M$, de Min C. Emapalumab in children with primary hemophagocytic lymphohistiocytosis. N Engl J Med. 2020;382:1811-22. 